\title{
Lead Poisoning Frequency and its Associated Factors
}

\section{Research Article}

\author{
Ahmad Talebian ${ }^{1}$, Saba Karim², Abbas Dashgar ${ }^{3}$, Hamid Reza Saberi ${ }^{3 *}$ \\ 1. Pediatric neurologist, Department of Pediatrics, Faculty of Medicine, Kashan University of Medical sciences, Kashan, Iran \\ 2. Instructor, Faculty of Nursing and Midwifery, Kermanshah University of Medical Sciences, Kermanshah. Iran. \\ 3. Pediatrician, Department of Pediatrics, Faculty of Medicine, Kashan University of Medical sciences, Kashan, Iran \\ 4. Occupational Medicine Specialist, Associate Professor, Kashan University of Medical sciences, \\ Social Determinants Health Research Center Kashan, Iran.
}

\begin{abstract}
Background: Despite wide range of measures to control lead pollution in recent decades, this heavy metal poisoning remains as a health problem in all societies particularly industrialized communities. In this study, frequency of lead poisoning and its related factors in 2-12 years old children in Kashan-Iran were evaluated. Methods: This cross sectional study was conducted on 150 healthy children referred to health centers to receive routine health care. Samples were selected based on cluster. Serum lead levels determined by atomic spectroscopy. Results: The mean lead levels in children were $9.27 \pm 9.55 \mu \mathrm{g} / \mathrm{dl}$. The frequency of lead poisoning was $30.0 \%$ and it was related to moderate social status $(\mathrm{OR}=1.72,95 \% \mathrm{CI}=1.04-2.86, \mathrm{p}=0.03)$ and weak economic status $(\mathrm{OR}=3.12$, $95 \% \mathrm{CI}=1.69-5.56, \mathrm{p}<0.001)$. There were no significant relation between age, gender and place of residence and lead poisoning. Conclusion: Lead poisoning was found to be prevalent and is related to the socio-economic situation.
\end{abstract}

Keywords: Lead, Serum levels, socioeconomic state.

\section{Introduction}

Lead is one of the most important environmental pollutants that can causes neurological damage and behavioral disorders (1). Although all age groups are exposed to lead contamination, fetuses and children are at the greater risk because the absorption rate in children is higher than the adults $(2 \& 3)$. The lead can absorb through the respiratory tract, digestive system and skin. After absorption, lead pollute blood cells, soft tissue and bones $(4 \& 5)$. Lead absorption affected by dietary factors, nutritional status, and metal mode (6). In adults, 5-15\% foods' lead are absorbed, and in children, due to physiological and metabolic differences, this amount ranges from 30 to $40 \%$ (7-9).

Lead has many destructive effects, which affects many organs of the body. It transmitted from mother to fetus and affects infants due to secretion into the mother's milk $(10 \& 11)$. This element affects the central and peripheral nervous system. Irritability, fatigue, anxiety, insomnia, dizziness and seizure are some of the central effects of the lead (12-14). Other complications such as memory loss, visual impairment, and hearing loss have also been observed in lead poisoning (15 \& 16). High levels of lead (100-200 $\mu \mathrm{g} /$ dL in adults and $80-100 \mu \mathrm{g} / \mathrm{dL}$ in children) can cause encephalopathy. Excessive lead exposure in the children reduces Intelligence Quotient (IQ) and shortterm memory and impair read, write and other motor skills (13-15).

\section{*Corresponding Author:}

\section{Hamid Reza Saberi}

Occupational medicine specialist, Associate Professor,

Kashan university of medical sciences ,

Social Determinants Health Research Center,

Kashan Iran.

Email id: hamisa2002@yahoo.com

Studies in Iran show a high prevalence of lead poisoning in children. Farhat et al. indicates that $74.8 \%$ of the children aged 1 to 7 years are contaminated with lead (18). In a survey of 320 primary school students in Semnan, Franoosh et al. pollution was reported at $78.8 \%$ (19). In another study in Yazd, it was found that 93.1\% of children in this city have a serum lead level higher than allowed limits (20).

Another study was conducted to determine the relationship between spiritual health and depression, anxiety, and stress among the students of Ilam University of medical sciences in 1395. This is a descriptive-cross sectional study that was performed on 300 randomly selected students of Ilam University of medical sciences in 1395. In order to measure the level of spiritual health among the participants, PaloutzianEllison's 20-item standard questionnaire was utilized and DASS-21 questionnaire was used to measure variables depression, anxiety, and stress. Findings: In the present study, of 300 subjects under investigation, 194 subjects (64.6 percent) were female. The highest frequencies for depression, anxiety, severe stress, and extremely severe stress were observed among single subjects (12, 20, and 10.6 respectively). Pearson's correlation coefficient indicated that there is a statistically significant linear correlation between the mean score of spiritual health and the level of depression, anxiety, and stress in students $(p=0.001)$. Conclusion: Results of this research showed a positive correlation between spiritual health and indices depression, anxiety, and stress among students of Islam University of medical sciences. Accordingly, it can be said that acquiring skills in the domain of spiritual health for medical sciences students is as necessary as acquiring nursing and medical care skills (21).

Considering the significant effects of lead on children's health, necessity of contamination control and 
lack of sufficient information about the status of children's lead contamination in Kashan- Iran, This study was conducted to evaluate the frequency of lead poisoning and its related factors.

\section{Methods}

This cross-sectional study was conducted on 150 healthy children in Kashan who were referred to health centers in order to receive routine health care. Cluster sampling was used to access the appropriate research community. For this purpose, a health care center was randomly selected from each of the five areas of Kashan. The required number of samples from each center was calculated based on the covered population and finally, by random sampling, participates were selected in each center. Children with congenital anomalies, hematological disorders such as thalassemia, chronic illness and malignancies were excluded from study.

After providing information about the goals and methods of the study, informed consent was obtained from the child's parents. The children's demographic information including age, sex, place of residence, economic and social status of the family were obtained and recorded in designed questionnaire. The socioeconomic status of the family was studied using socioeconomic status questionnaire designed by Garmaroodi et al. (22). According to the results of this questionnaire, the families were divided into four socioeconomic groups: weak, moderate, good and excellent.

Six milliliter of venous blood was taken by a qualified nurse. The blood was stored in two separate tubes. One sample for complete blood cells counting was sent to the referral laboratory of Kashan University of Medical Sciences. Another sample after centrifugation and serum separation was frozen at $-20{ }^{\circ} \mathrm{C}$. After the completion of sampling, serum samples were defreezing and serum lead levels were measured by atomic spectrometry method (Flame Atomic Absorption Spectroscopy, Spect AA.20 instrument and SOPS:743992-1 CASRN). Serum lead levels higher than $10 \mu \mathrm{g} / \mathrm{dL}$ was considered as lead poisoning.

Data were analyzed using SPSS software version 18. Qualitative results have been reported as absolute and relative frequency and quantitative results have been reported as mean \pm standard deviation. Chi-square, Oneway ANOVA and T-test were used for data analysis. The $p$ value less than 0.05 was considered significant, (To test the relationship between variables, Pearson and Spearman was used).

\section{Results}

This study was conducted to determine the frequency of lead contamination and its related factors on 150 children aged 2-12 years. The mean age of the children was $6.75 \pm 3.54$ years. The place of residence of $68(45.3 \%)$ of participants was the city and $82(54.7 \%)$ people was the village and the city border. Table 1 shown participants' basic characteristics.

The mean serum levels of lead was $9.27 \pm 9.55 \mu \mathrm{g} /$ dL. Mean serum concentrations of lead in male and female children were $9.92 \pm 9.93$ and $8.6 \pm 9.15 \mu \mathrm{g} / \mathrm{dL}$, respectively. Overall, 45 children $(30.0 \%)$ has lead serum level higher than $10 \mu \mathrm{g} / \mathrm{dL}$. Male children aged 5-9 years living in village and suburbs that had moderate social and weak economic status had the highest levels of lead poisoning. Moderate social status (odds ratio $=1.72,95 \%$ confidence Interval $=1.04-2.86, \quad \mathrm{p}=0.03)$ and weak economic status (odds ratio $=3.12,95 \%$ confidence Interval $=1.69-5.56, \mathrm{p}<0.001)$ were associated with lead poisoning. Factors associated with lead poisoning are shown in Table 2.

According to Table 3, The highest frequency of serum levels above $10 \mu \mathrm{g} / \mathrm{dl}$ was observed in children with poor socioeconomic status. $65.1 \%$ of people with a poor socioeconomic status had a serum level above $5 \mu \mathrm{g} /$ $\mathrm{dL}$, which is in the family. The average and good situation was $55.7 \%$ and $17.23 \%$, respectively. There was a significant relationship between the socioeconomic status of the family and serum lead level in the children (Table 3).

Also Lead levels were found to be less than 5 and 9.9-5 $\mu \mathrm{g} / \mathrm{dL}$ in children resident in the city, while the highest frequency of serum lead levels was higher than 10 $\mu \mathrm{g} / \mathrm{dl}$ for children in the outskirts of the city. The difference between the two groups was not statistically significant $(\mathrm{p}=0.05)$ (Table 4).

Based on the results of this study, children living in homes less than 10 years of age had the highest frequency of serum lead levels below $5 \mu \mathrm{g} / \mathrm{dL}$. Also, children living in homes 10 to 10 years of age have the highest serum levels of more than 10 micrograms per deciliter. There was a statistically significant relationship between age of place of residence and serum level of lead in children $(\mathrm{P}=0.0001)$ (Table 5).

\section{Discussion}

This study was conducted to evaluate the serum levels, frequency of lead poisoning and its related factors in children aged 12-29 years old in Kashan. In this study, the mean serum lead level in children was $9.27 \pm 9.55 \mu \mathrm{g} /$ dL. Few studies have been done in Iran to study the serum levels of lead in children. In a study Daroogar et al. compare serum lead levels in children with ADHD and healthy children in Tehran, serum lead level in healthy children was $7.19 \pm 3.19 \mu \mathrm{g} / \mathrm{dL}$ and in children with ADHD was $7.2 \pm 2.36 \mu \mathrm{g} / \mathrm{dL}$ (23). Khosravi et al. investigated the serum level of lead in neonate's umbilical cord blood in a study that was performed on 60 newborn infants from 2011 to 2012 years. It was found that mean serum lead level in umbilical cord blood of these infants was $2.97 \pm 2.24 \mu \mathrm{g} / \mathrm{dL}$ (24). In a study in Mashhad, Farhat et al. examined 206 children aged 1 to 7 referring to the pediatric emergency department in 2001 2003. In this study, the mean serum lead level in healthy children was $11.8 \pm 32.1 \mu \mathrm{g} / \mathrm{dl}$ and in children with seizure it was $12.65 \pm 3.6 \mu \mathrm{g} / \mathrm{dL}$ (25). Although serum levels of lead in this study were higher than those in Tehran, the frequency of lead poisoning was lower than what has been reported by Khosravi et al (24). The higher serum levels of lead in the Farhat's study be due to the differences in the methods and place of sampling. However, the reported amounts in the above studies indicate that there are notable sources of pollution in the community that serious actions must be taken to control them.

In this study, lead poisoning was found to be associated with the economic and social status of the 
family. In a study conducted by Etchevers et al. In France in 2009-2008, 3831 patients referred to the hospital were evaluated for serum levels of lead and its related factors, and it was found that only $0.9 \%$ of children had higher levels of $10 \mu \mathrm{g} / \mathrm{dL}$ of lead. The associated factors with lead levels poisoning were the use of tap water, scaled wall paintings, reconstruction of old homes, and handsmouth habit and exposure to cigarette smoke (26). In another study, Bernard et al. examined the risk factors associated with high serum levels of lead. In this study, which evaluated data from 1988 to 1988 , the NonHispanic race, home age, country, and economic levels were associated with lead poisoning (27). Edwards et al. described drinking water as the most important factor associated with serum lead levels in young children in the United States (28). In a study by Levin et al., The risk factors of lead poisoning in United States' children were studied and it was found that age, race and ethnicity, income level, Location age, place of residence and occupation of parents were the most important factors associated with serum lead levels in children. (29).

Hore and his colleagues reviewed the lead serum levels and its related factors in a study in 2016 on 230 South Asian child and adult residents in New York. In this study, it was found that race, ethnicity and recent home renovation are the most important factors associated with high serum lead levels in these individuals (30). Pelc et al. examined the environmental and socioeconomic factors of the children of the industrial zone of Silesia in Europe. In this study, 4882 people aged 3 to 18 years were surveyed during the years of 1998-1998. Parents' low levels of education, unemployment, parental employment, low socioeconomic status, smoking at home, living in underground buildings and consuming native fruits and vegetables were identified as factors associated of higher lead levels lead in children (31). Another study in Taiwan has examined the factors associated with lead poisoning in the suburbs of Thailand. Contacting with solar energy batteries and the use of non-standard cookware were the lead poisoning related factors (32). In another similar study done in China, gender, height, weight, consuming more beans, greater use of canned foods, smoking by family members, proximity to the street, presence of electronics recycling centers and mother's education level has been mentioned as risk factors for higher serum levels of lead in Chinese children (33). Another study conducted in China indicated that the mother, age, male gender and lower education were the risk factors for more contamination with lead (34). These risk factors have been reported in similar survey conducted in Southwestern China for the sex of the boy, age, mother's age at birth and living in crowded places. (35).

Although many efforts have been made in recent years to reduce the sources of lead release in different societies, lead poisoning continues to be a major health problem with significant effects in all societies, especially industrialized countries. According to the results of this study and the mentioned studies, the correction of many risk factors for lead poisoning is difficult or impossible. Therefore, it seems that the most effective and easiest way to prevent lead poisoning in children is to eliminate sources of dissemination.

Table 1. Basic characteristics of participants

\begin{tabular}{|l|c|c|}
\hline \multirow{2}{*}{ Variables } & \multicolumn{2}{|c|}{ Gender groups } \\
\cline { 2 - 3 } & $\begin{array}{c}\text { Male } \\
\text { Number } \\
\text { (percent) }\end{array}$ & $\begin{array}{c}\text { Female } \\
\text { Number } \\
\text { (percent) }\end{array}$ \\
\hline $\begin{array}{c}\text { Age group } \\
2-4\end{array}$ & $25(32.5)$ & $26(35.6)$ \\
$5-9$ & $28(36.4)$ & $32(43.8)$ \\
$10-12$ & $24(31.2)$ & $15(20.5)$ \\
\hline Place of residence & $36(46.8)$ & $32(43.8)$ \\
City & $41(53.2)$ & $41(56.2)$ \\
Countryside & $34(44.2)$ & $35(47.9)$ \\
\hline Economic Status & $32(41.6)$ & $20(27.4)$ \\
Weak & $11(14.3)$ & $18(24.7)$ \\
Moderate & $28(36.4)$ & $22(30.2)$ \\
Good & $42(54.5)$ & $25(34.2)$ \\
\hline Social Status & $7(9.1)$ & $26(35.6)$ \\
Weak & & \\
Moderate &
\end{tabular}

Table 2. Related factors of Lead poisoning

\begin{tabular}{|c|c|c|c|c|}
\hline \multirow[b]{2}{*}{ Variables } & \multicolumn{2}{|c|}{ Lead poisoning } & \multirow[b]{2}{*}{ OR $(95 \% \mathrm{CI})$} & \multirow[b]{2}{*}{$P$ value } \\
\hline & $\begin{array}{c}\text { No } \\
\text { Number (percent) }\end{array}$ & $\begin{array}{c}\text { Yes } \\
\text { Number (percent) }\end{array}$ & & \\
\hline $\begin{array}{l}\text { Age group } \\
2-4 \\
5-9 \\
10-12\end{array}$ & $\begin{array}{l}37(35.2) \\
41(39.0) \\
27(25.8)\end{array}$ & $\begin{array}{l}14(31.1) \\
19(42.2) \\
12(26.7)\end{array}$ & $1.09(0.69-1.71)$ & 0.88 \\
\hline $\begin{array}{l}\text { Place of residence } \\
\text { City } \\
\text { Countryside }\end{array}$ & $\begin{array}{l}53(77.95) \\
52(63.42)\end{array}$ & $\begin{array}{l}15(22.05) \\
30(36.58)\end{array}$ & $2.04(0.98-4.22)$ & 0.05 \\
\hline $\begin{array}{l}\text { Economic Status } \\
\text { Weak } \\
\text { Moderate } \\
\text { Good } \\
\end{array}$ & $\begin{array}{l}39(37.1) \\
38(36.2) \\
28(26.7) \\
\end{array}$ & $\begin{array}{c}30(66.7) \\
14(31.1) \\
1(2.2) \\
\end{array}$ & $3.12(1.69-5.56)$ & $<0.001$ \\
\hline $\begin{array}{l}\text { Social Status } \\
\text { Weak } \\
\text { Moderate } \\
\text { Good }\end{array}$ & $\begin{array}{l}31(29.5) \\
46(43.8) \\
28(26.7)\end{array}$ & $\begin{array}{c}19(42.2) \\
21(46.7) \\
5(11.1)\end{array}$ & $1.72(1.04-2.86)$ & 0.03 \\
\hline
\end{tabular}


International Journal of Ayurvedic Medicine, 2018, 9(3), 191-195

Table 3: Frequency of serum lead level in terms of socio-economic status in children under study

\begin{tabular}{|c|c|c|c|c|}
\hline \multirow{2}{*}{$\begin{array}{c}\text { Socio-economic } \\
\text { status }\end{array}$} & \multicolumn{3}{|c|}{ Serum lead level $\mu \mathrm{g} / \mathrm{dl}$} & \multirow{2}{*}{ Total } \\
\cline { 2 - 4 } & $\begin{array}{c}>5 \\
\text { Number (percent) }\end{array}$ & $\begin{array}{c}9 / 9-5 \\
\text { Number (percent) }\end{array}$ & $\begin{array}{c}<10 \\
\text { Number (percent) }\end{array}$ & \\
\hline Weak & $24(34.78)$ & $15(21.73)$ & $30(43.47)$ & $69(100)$ \\
\hline Moderate & $23(44.23)$ & $15(28.84)$ & $14(26.92)$ & $52(100)$ \\
\hline Good & $23(79.31)$ & $5(17.24)$ & $1(0.03)$ & $29(100)$ \\
\hline Total & $70(46.67)$ & $35(23.33)$ & $45(30)$ & $150(100)$ \\
\hline
\end{tabular}

Table 4: Frequency of serum lead level in terms of place of living in children under study

\begin{tabular}{|c|c|c|c|c|}
\hline \multirow{2}{*}{ Location } & \multicolumn{3}{|c|}{ Serum lead level $\mu \mathrm{g} / \mathrm{dl}$} & \multirow{2}{*}{ Total } \\
\cline { 2 - 4 } & $\begin{array}{c}>5 \\
\text { Number (percent) }\end{array}$ & $\begin{array}{c}9 / 9-5 \\
\text { Number (percent) }\end{array}$ & $\begin{array}{c}<10 \\
\text { Number (percent) }\end{array}$ & \\
\hline City & $39(57.37)$ & $14(20.58)$ & $15(22.05)$ & $68(100)$ \\
\hline Countryside & $31(37.8)$ & $21(25.6)$ & $30(36.58)$ & $82(100)$ \\
\hline Total & $70(46.67)$ & $35(23.33)$ & $45(30)$ & $150(100)$ \\
\hline
\end{tabular}

Table 5:Frequency of serum lead levels based on the age of residence in children under study

\begin{tabular}{|c|c|c|c|c|}
\hline \multirow{2}{*}{$\begin{array}{c}\text { Age of residence } \\
\text { based on year }\end{array}$} & \multicolumn{3}{|c|}{ Serum lead level $\mu \mathrm{g} / \mathrm{dl}$} & \multirow{2}{*}{ Total } \\
\cline { 2 - 4 } & $\begin{array}{c}>5 \\
\text { Number (percent) }\end{array}$ & $\begin{array}{c}9 / 9-5 \\
\text { Number (percent) }\end{array}$ & $\begin{array}{c}<10 \\
\text { Number (percent) }\end{array}$ & \\
\hline$>10$ & $35(61.4)$ & $16(28.07)$ & $6(10.52)$ & $57(100)$ \\
\hline $10-20$ & $26(39.39)$ & $16(24.24)$ & $24(36.36)$ & $66(100)$ \\
\hline$<20$ & $9(33.33)$ & $3(11.11)$ & $15(55.55)$ & $27(100)$ \\
\hline Total & $70(100)$ & $35(23.33)$ & $45(30)$ & $150(100)$ \\
\hline
\end{tabular}

\section{References}

1. Dapul H, Laraque D. Lead poisoning in children. Adv Pediatr. 2014; 61(1):313-33.

2. Majid H, Khan AH, Khan NU, Siddiqui I, Ghani F, Jafri L. High Burden of Subclinical Lead Toxicity after Phase Out of Lead from Petroleum in Pakistan. J Coll Physicians Surg Pak. 2017; 27(12):767-70.

3. Tong S, Schirding YE, prapamontal $T$. Environmental lead exposure: a public health problem of global dimensionBull. Bull World Health Organ. 2000;78(9):1068-77.

4. Yabe J, Nakayama SM, Ikenaka Y, Yohannes YB, Bortey-Sam N, Oroszlany B, et al. Lead poisoning in children from townships in the vicinity of a leadzinc mine in Kabwe, Zambia. Chemosphere. 2015; 119:941-7.

5. Bose-O'reilly S, Yabe J, Makumba J, Schutzmeier P, Ericson B, Caravanos J. Lead intoxicated children in Kabwe, Zambia. Environ Res. 2017.

6. Galal-Gorchev H. Dietary intake of pesticide residues: cadmium, mercury, and lead. Food Addit Contam. 1991;8(6):793-806.

7. Hon KL, Fung CK, Leung AK. Childhood lead poisoning: an overview. Hong Kong Med J. 2017; 23(6):616-21.

8. Panahandeh G, Khoshdel A, Heidarian E, Amiri M, Rahiminam H. Blood Lead Levels in Children of Southwest Iran, Aged 2-6 Years and Associated
Factors. J Clin Diagn Res. 2017; 11(7):SC01-SC4.

9. Caito S, Aschner M. Developmental Neurotoxicity of Lead. Adv Neurobiol. 2017; 18:3-12.

10. Rebelo FM, Caldas ED. Arsenic, lead, mercury and cadmium: Toxicity, levels in breast milk and the risks for breastfed infants. Environ Res. 2016; 151:671-88.

11. Shawahna R, Zyoud A, Dwikat J, El-Helo M, Yacoub B, Hilal H. Breast Milk Lead Levels in 3 Major Regions of the West Bank of Palestine. J Hum Lact. 2016; 32(3):455-61.

12. Greig J, Thurtle N, Cooney L, Ariti C, Ahmed AO, Ashagre $\mathrm{T}$, et al. Association of blood lead level with neurological features in 972 children affected by an acute severe lead poisoning outbreak in Zamfara State, northern Nigeria. PLoS One. 2014; 9 (4):e93716.

13. Ahamed M, Fareed M, Kumar A, Siddiqui WA, Siddiqui MK. Oxidative stress and neurological disorders in relation to blood lead levels in children. Redox Rep. 2008; 13(3):117-22.

14. Bellinger DC. Neurological and behavioral consequences of childhood lead exposure. PLoS Med. 2008; 5(5):e115.

15. Flores-Montoya MG, Alvarez JM, Sobin C. Olfactory recognition memory is disrupted in young mice with chronic low-level lead exposure. Toxicol 
Lett. 2015; 236(1):69-74.

16. Seo J, Lee BK, Jin SU, Park JW, Kim YT, Ryeom $\mathrm{HK}$, et al. Lead-induced impairments in the neural processes related to working memory function. PLoS One. 2014; 9(8):e105308.

17. Ferlemi AV, Avgoustatos D, Kokkosis AG, Protonotarios V, Constantinou C, Margarity $\mathrm{M}$. Lead-induced effects on learning/memory and fear/ anxiety are correlated with disturbances in specific cholinesterase isoform activity and redox imbalance in adult brain. Physiol Behav. 2014; 131:115-22.

18. Farhat AS, Parizadeh SM, Balali M, Khademi GR. Comparison of blood lead levels in 1-7 year old children with and without seizure. Neurosciences. 2005;10 (3): 210-212.

19. Faranoush M, Malek M, Ghorbani R, Rahbar M, Safaei Z. Study of the blood lead levels and related factors in the 6-11 years old children in Semnan . koomesh. 2003; 4 (3) :79-86. [Article in Persian]

20. Dehghan L, Ghane A. Study of the blood lead levels in the 2-12 years old children in Yazd. [dissertation]. Yazd University of Medical Science. 2000. [Article in Persian]

21. SeyedRahmatollah Mousavimoghadam, Mostafa Madmoli, Sasan Nikpay, An investigation of the relationship between spiritual health and depression, anxiety, and stress among students of Ilam University of medical sciences, J Res Med Dent Sci, 2018, 6(3): 294-300, DOI: 10.24896/ jrmds.20186345

22. Garmaroudi GH, Moradi A. Socio-Economic Status in Iran: A study of measurement index.Payesh. 2010;9(2):137-144. [Article in Persian]

23. Daroogar S, davari R, Kamran Lalbakhsh A. The association of attention deficit hyperactivity disorder and blood lead level among children less than 10 years old referred to Tehran hospitals between 2007 and 2010. Med Sci. 2012; 22 (1) :5761. [Article in Persian]

24. Khosravi N, Khalesi N, Noorbakhsh S, Tabatabaei A, Ahmadi B, Asgarian R et al . Serum lead levels of cord blood in newborn immediately after birth. Tehran Univ Med J. 2014; 72 (8) :540-545. [Article in Persian]

25. Farhat AS, Parizadeh SM, Balali M, Balali M, Khademi GR. Comparison of blood lead levels in 17 year old children with and without seizure. Neurosciences (Riyadh). 2005; 10(3):210-2.

26. Etchevers A, Bretin P, Lecoffre C, Bidondo ML, Le Strat Y, Glorennec P, et al. Blood lead levels and risk factors in young children in France, 2008-2009. Int J Hyg Environ Health. 2014; 217(4-5):528-37.
27. Bernard SM, Mcgeehin MA. Prevalence of blood lead levels $>$ or $=5$ micro $\mathrm{g} / \mathrm{dL}$ among US children 1 to 5 years of age and socioeconomic and demographic factors associated with blood of lead levels 5 to 10 micro g/dL, Third National Health and Nutrition Examination Survey, 1988-1994. Pediatrics. 2003; 112 (6 Pt 1):1308-13.

28. Edwards M, Triantafyllidou S, Best D. Elevated blood lead in young children due to leadcontaminated drinking water: Washington, DC, 2001-2004. Environ Sci Technol. 2009; 43(5):161823.

29. Levin R, Brown MJ, Kashtock ME, Jacobs DE, Whelan EA, Rodman J, et al. Lead exposures in U.S. Children, 2008: implications for prevention. Environ Health Perspect. 2008; 116(10):1285-93.

30. Hore P, Ahmed MS, Sedlar S, Saper RB, Nagin D, Clark N. Blood Lead Levels and Potential Risk Factors for Lead Exposures Among South Asians in New York City. J Immigr Minor Health. 2016.

31. Pelc W, Pawlas N, Dobrakowski M, Kasperczyk S. Environmental and socioeconomic factors contributing to elevated blood lead levels in children from industrial area of Upper Silesia. Environ Toxicol Chem. 2016.

32. Swaddiwudhipong W, Kavinum S, Papwijitsil R, Tontiwattanasap W, Khunyotying W, Umpan J, et al. Personal and Environmental Risk Factors Significantly Associated with Elevated Blood Lead Levels in Rural Thai Children. Southeast Asian J Trop Med Public Health. 2014; 45(6):1492-502.

33. Guo P, Xu X, Huang B, Sun D, Zhang J, Chen X, et al. Blood lead levels and associated factors among children in Guiyu of China: a population-based study. PLoS One. 2014; 9(8):e105470.

34. Xie XH, Tan ZW, Jia N, Fan ZY, Zhang SM, Lu YY, et al. Blood lead levels among children aged 0 to 6 years in 16 cities of China, 2004-2008. Chin Med J (Engl). 2013; 126(12):2291-5.

35. Liu J, Ai Y, Mccauley L, Pinto-Martin J, Yan C, Shen $\mathrm{X}$, et al. Blood lead levels and associated sociodemographic factors among preschool children in the South Eastern region of China. Paediatr Perinat Epidemiol. 2012; 26(1):61-9.

36. Balalian A, Arin, Simonyan, Hambardzum, Hekimian, Kim, Deckelbaum, Richard J., Sargsyan, Aelita. Prevalence and determinants of stunting in a conflict-ridden border region in Armenia - a crosssectional study. BMC Nutrition 3 (1):85. 2017. 10.1186/s40795-017-0204-9. 